5. Savchenko O. Ya. Vykhovnyi potentsial pochatkovoi osvity [Tekst] : posibnyk dlia vchyteliv i metodystiv pochat. navchannia. 2-he vyd., dopovn., pererobl. K. : Bohdanova A. M., 2009. - $226 \mathrm{~s}$.

6. Tkachenko H.M. Vykhovannia shkoliariv zasobamy slova $u$ tvorchii spadshchyni V.O.Sukhomlynskoho : dys. kand. ped. nauk : 13.00.01. Kyiv, 2000. $-203 \mathrm{~s}$.

Одержано статтю: 18.09.2019

Прийнято до друку: 16.10.2019

УДК $378.22: 373.2$

DOI: $10.15330 /$ esu. $17.258-264$

\author{
Маріанна Матішак, \\ кандидат педагогічних наук, доцент, \\ ДВНЗ “Прикарпатський національний \\ університет імені Василя Стефаника" \\ (м. Івано-Франківськ, Україна) \\ Marianna Matishak, \\ Candidate of pedagogical sciences (PhD), \\ Associate Professor, Vasyl Stefanyk Precarpathian \\ National university (Ivano-Frankivsk, Ukraine) \\ mariannamatishak@ukr.net
}

\author{
Ірина Скоморовська, \\ кандидат педагогічних наук, доцент, \\ ДВНЗ "Прикарпатський національний \\ університет імені Василя Стефаника" \\ (м. Івано-Франківськ, Україна) \\ Iryna Skomorovska, \\ Candidate of pedagogical sciences ( $\mathrm{PhD})$, \\ Associate Professor, Vasyl Stefanyk Precarpathian \\ National university (Ivano-Frankivsk, Ukraine) \\ iskomor@ukr.net \\ Ірина Дідух, \\ кандидат педагогічних наук, доцент, \\ ДВНЗ "Прикарпатський національний \\ університет імені Василя Стефаника" \\ (м. Івано-Франківськ, Україна) \\ Iryna Didukh, \\ Candidate of pedagogical sciences $(\mathrm{PhD})$, \\ Associate Professor, Vasyl Stefanyk Precarpathian \\ National university (Ivano-Frankivsk, Ukraine) \\ mail@pnu.edu.ua
}

\title{
ФОРМУВАННЯ ДЕМОКРАТИЧНОЇ КУЛЬТУРИ МАЙБУТНІХ МАГІСТРІВ ДОШКІЛЬНОЇ ОСВІТИ: ОСОБИСТІСНО ОРІЕНТОВАНИЙ ПІДХІД
}

\section{FORMING OF DEMOCRATIC CULTURE OF FUTURE MASTERS OF PRESCHOOL EDUCATION: A PERSONALLY ORIENTED APPROACH}

У статті проаналізовано теоретико-методологічні аспекти формування демократичної культури майбутніх магістрів доикільної освіти в освітньому прочесі 3 ВО. Доведено, ио зміст та організачія професійної педагогічної підготовки в умовах магістратури мас передбачати формування готовності майбутніх фахівців освітньої сфери до здійснення професійної діяльності на засадах демократичних чінностей та гуманістичних вимірів. У статті виокремлено основні положення реалізачії особистісно орієнтованого підходу під час формування демократичної культури студентів в умовах магістратури, а саме: ціннісно-змістове наповнення навчальних дисциплін; формування професійно значуцих якостей демократичної особистості; використання активних форм $і$ 
методів у освітньому прочесі ЗВО; стимулювания партнерських відносин між усіма учасниками освітнього прочесу.

Ключові слова: демократична культура, особистісно оріснтований підхід, майбутні магістри, доикільна освіта.

The article analyzes the theoretical and methodological aspects of forming the democratic culture of future masters of pre-school education in the educational process of higher education establishments. Based on the analysis of recent research and scientific publications, substantiation of the essence of key concepts has been made the purpose, tasks, specificity of democratization of higher pedagogical education have been characterized. It is proved that the content and organization of professional pedagogical training in the conditions of the magistracy should provide for the formation of the readiness of future specialists to pursue professional activity on the basis of democratic values and humanistic dimensions. This approach is in line with trends in reforming the higher education system in line with European standards.

The authors propose pedagogical conditions aimed at the effective mastering of the future masters in the culture of democracy while studying at higher education establishment. In the article the main provisions of realization of personally oriented approach during formation of democratic culture of students in the conditions of magistracy are distinguished, namely: valuemeaningful content of educational disciplines; formation of professionally important qualities of a democratic personality; the use of active forms and methods in the educational process of university; promoting partnerships between all participants in the educational process. It has been determined that democratization cannot be an end in itself of the educational process, since the leading goal should be to create the most favorable conditions for self-realization of the individual and to reveal the creative pedagogical potential of future masters in the field of preschool education. education.

Key words: democratic culture, personality-oriented approach, future masters, preschool

Постановка проблеми. Сучасна система освіти на всіх рівнях потребує висококваліфікованих фахівців, активних, креативних здатних до розвитку i самовдосконалення. Успіх професійної діяльності особистості в освітній галузі значною мірою залежить від уміння вибудувати систему соціальних зав'язків, конструктивної взасмодії з усіма учасниками освітнього процесу: здобувачами освіти, їх батьками, колегами, керівництвом. Основою для побудови партнерських стосунків $є$ демократична культура особистості, зміст якої становлять цінності свободи думки і висловлювань, толерантності, взаємоповаги, взаєморозуміння тощо.

Особливої уваги потребує організація освітнього процесу на рівні магістратури, оскільки рівень кваліфікації магістрів педагогічних спеціальностей передбачає розв'язання професійних завдань інноваційного характеру, педагогічну діяльність у закладах освіти різного рівня, управління робочими чи навчальними процесами, а також викладання навчальних дисциплін відповідно до спеціальності у закладах вищої освіти. Зміст професійної діяльності магістрів дошкільної освіти залежить від напряму, в якому реалізується фахівець, відповідно до одержаної кваліфікації та посади, як-от: керівник, методист чи вихователь закладів дошкільної освіти, викладач педагогіки і психології (дошкільної) в закладах вищої освіти тощо. Демократичні цінності в перелічених напрямах діяльності магістрів-педагогів сприяють налагодженню суб'єкт-суб'єктних відносин між усіма учасниками освітнього процесу і сприяють успішній професійній самореалізації. Отож, процес професійної підготовки майбутніх педагогів має грунтуватися на демократичних цінностях i передбачати формування культури демократії майбутніх фахівців освітньої галузі. 
Аналіз останніх досліджень i публікацій. Про актуальність проблеми демократизації освітнього процесу свідчить низка наукових публікацій, присвячених різним аспектам порушеної проблеми, а саме: демократичні засади організації освітнього процесу розглядають В.Андрущенко, Т.Іванова, В.Кремень, В.Огнев 'юк, І.Силадій, О.Сухомлинська та інші; методологічні особливості засвоєння здобувачами освіти принципів демократії та формування відповідних компетентностей вивчають С.Кострюков, Г.Назаренко, Л.Панченко, І.Сопівник та інші. Зазначимо, шо проблематика особистісно орієнтованого підходу в системі освіти не втрачає актуальності упродовж тривалого часу, про що свідчать наукові розвідки таких учених як І.Бех, І.Зязюн, С.Сисоєва, І.Якиманська та інші.

Попри значну кількість напрацювань в окреслених напрямах, потребують вивчення питання методологічних засад формування демократичної культури студентської молоді й, зокрема, майбутніх магістрів дошкільної освіти. Як свідчать результати аналізу наукових джерел, до методологічних підходів у системі професійної підготовки майбутніх педагогів відносять системний, особистісно орієнтований, компетентнісний, діяльнісний, акмеологічний, контекстний та низку інших. 3-поміж перелічених вважаємо за необхідне конкретизувати специфіку особистісно орієнтованого підходу й навести практичні рекомендації для його успішної реалізації у процесі формування культури демократії магістрів дошкільної освіти.

Мета статті - виявити особливості формування культури демократії майбутніх магістрів дошкільної освіти за умов реалізації особистісно орієнтованого підходу в процесі їх професійної підготовки.

Виклад основного матеріалу. Демократизація освітнього простору в широкому розумінні є одним із пріоритетних напрямів державної політики в освітній галузі України. У Законі України "Про освіту" виокремлено основні засади та принципи освітньої діяльності, з-поміж яких вагоме місце займає демократизм, формування громадянської культури та культури демократії в здобувачів освіти. А до ключових компетентностей, якими має оволодіти особистість, здобуваючи освіту, віднесено громадянські та соціальні, що "грунтуються на ідеях демократії, справедливості, рівності, прав людини, добробуту та здорового способу життя, 3 усвідомленням рівних прав і можливостей" [3].

У Національній стратегії розвитку освіти в Україні на період до 2021 року вказано, що "якісна освіта $\epsilon$ необхідною умовою забезпечення сталого демократичного розвитку суспільства", а також визначено пріоритети державної політики в сфері освіти, яка має забезпечити "послідовну демократизацію і гуманізацію навчально-виховного процесу, педагогічної ідеології в цілому, тобто на європейські гуманістичні цінності та виміри" [10].

Положення нормативно-правових актів щодо демократизації освіти в Україні суголосні результатам наукових досліджень порушеної проблеми. У наукових розвідках дослідники визначають мету демократичної освіти, а саме: “виховання громадян 3 незалежним, допитливим, аналітичним світоглядом, проте глибоко обізнаних $з$ правилами і практикою демократії; .. . з відповідальною громадянською позицією" [4, с. 30-31]; “гідне життя особистості; рівні освітні можливості для кожного індивіда незалежно від статі, соціального стану, національності тощо; підтримка економічних, політичних і соціальних умов для вільного існування людей; використання демократичних методів в організації освітнього процесу, в управлінні, в класі (навчальній групі) тощо" [1]. 
Водночас у змісті нормативно-правових актів $[3 ; 5 ; 10]$ та результатах наукових досліджень $[1 ; 4 ; 7 ; 11]$ прослідковується думка про те, що одним із завдань демократизації освітнього процесу на різних рівнях $є$ забезпечення відповідності національної системи освіти європейським стандартам та гуманістичним вимірам демократичного суспільства.

Т.Іванова та О.Фещенко виокремили сутнісні ознаки освіти, на які слід орієнтуватися, розглядаючи демократизацію як фундаментальну освітню ідею, а саме:

- доступність освіти для всіх людей незалежно від статевих, соціальних, національних, релігійних, расових ознак;

- децентралізація шкільної освіти завдяки праву місцевих органів влади розпоряджатися фінансами, добирати педагогічні кадри;

- відкритість і наступність усіх ступенів освіти в державі;

- право батьків на вибір освітнього закладу;

- орієнтація освітнього процесу на розвиток особистості вільної, творчої, активної [4, с. 31$]$.

Окрім перелічених цінностей, вагомим підгрунтям для демократизації освіти в Україні $є$ позитивні педагогічні здобутки минулих поколінь. 3 цього приводу І.Силадій наголошує на можливостях вибору педагогом освітньої траєкторії й зазначає, що розробляючи власну методику навчання і виховання педагог має творчо поєднувати традиції та інновації, спиратися на культурно-історичні та цивілізаційні особливості народу, а також позитивні педагогічні ідеї минулого [11, с. 279].

У контексті порушеної проблеми учені зазначають, що вища освіта має бути спрямована на навчання і виховання нового покоління молодих людей, які стануть лідерами демократичних змін у країні, допоможуть відродити забуті традиції, реалізовувати нові демократичні ідеї та принципи, цінності гуманізму в українському суспільстві [4, с. 31]. За свідченням О.Вишневського демократизація у вищій освіті здійснюється за окремими компонентами, а саме: структура освіти, управління освітою, процес, зміст і засоби навчання, кадрова політика [2, с. 32].

Магістерська підготовка має специфічні особливості, оскільки забезпечує формування готовності майбутніх фахівців до педагогічного, науково-педагогічного, наукового, управлінського видів діяльності. В усіх перелічених напрямах демократична культура особистості має вагоме значення. В Концепції розвитку педагогічної освіти зазначено, що "педагогічні працівники зі ступенем магістра мають бути здатними брати участь у створенні та впровадженні нового змісту освіти та новітніх методик (технологій) навчання, поєднувати власну педагогічну (науковопедагогічну, мистецько-педагогічну) діяльність на високому професійному рівні 3 поширенням кращої практики, експертною діяльністю та наставництвом на основі власного педагогічного досвіду" [9, с. 10].

Відповідно, зміст професійної педагогічної підготовки має передбачати формування готовності майбутніх фахівців освітньої сфери до здійснення професійної діяльності на засадах демократичних цінностей та гуманістичних вимірів освіти. Практичне втілення педагогіки гуманізму в освітній процес забезпечує низка методологічних підходів й особистісно оріснтований зокрема. Основоположні засади особистісно орієнтовного підходу в освітньому процесі представлені у наукових розвідках І.Беха, І.Зязюна, О.Пєхоти, С.Подмазіна, С.Сисоєвої, І.Якиманської та ін. Зокрема, С.Подмазін зазначає, що метою особистісно орієнтованого навчання i виховання $\epsilon$ розвиток у людини механізмів саморегуляції, самозахисту, адаптації, самореалізації задля формування діалогічних, безпечних способів взаємодії 3 
людьми, природою, культурою і формування самобутнього особистісного образу [8, c. 142].

У контексті професійної підготовки магістрантів Н.Мачинська об'єднує принцип гуманістичної спрямованості та особистісної орієнтації і наголошує, що гуманізація вищої педагогічної освіти - це один із шляхів інтеграції України в загальноєвропейський освітній простір, основними цінностями якого є права та свободи людини. Водночас дослідниця виокремлює низку правил у руслі гуманізації та особистісної оріснтованості педагогічної освіти, а саме: ставлення до студента як до самостійного суб'єкта, здатного навчатися добровільно за власним вибором, опертя на особистісну значущість учіння для кожного студента, використання механізмів взаєморозуміння, спілкування, співробітництва, формування в студентів різноманітних способів діяльності, творчих здібностей, необхідних для самореалізації особистості [7, с. 281-282]. М.Марусинець окреслює сучасні вимоги до викладача вищої школи й поміж інших акцентує увагу на таких, які сприяють особистісній орієнтованості професійної підготовки, як-от: здатність організовувати освітнє середовище 3 використанням проблемних завдань, розв'язання яких сприймається студентами як власна ініціатива; надання студентам можливостей для виявлення самостійності в інтелектуальній поведінщі; створення ситуації успіху в процесі навчання тощо [6, с. 86].

Узагальнення й систематизація результатів наукових розвідок, урахування потреб практики дозволили виокремити педагогічні умови реалізації особистісно орієнтованого підходу для формування культури демократії майбутніх магістрів дошкільної освіти, а саме:

1. Ціннісно-змістове наповнення навчальних дисциплін. В Концепції розвитку педагогічної освіти конкретизовано вимоги до модернізації освітніх програм підготовки магістрів і зазначено, що їх зміст має передбачати формування "соціально зрілої особистості педагогічного працівника, прийняття цінностей громадянського (відкритого демократичного) суспільства, повагу до держави та ії правової системи, усвідомлення обов'язку захисту України, національної ідентичності та толерування полікультурності, готовності до трансляції цих якостей учням" [9, с. 16]. У посібниках Ради Свропи виокремлено аксіологічну основу культури демократії, як-от: поціновування людської гідності та прав людини, визнання культурної різноманітності, цінності демократії, справедливості, рівності та верховенства права [5, c. 12].

У змісті навчальних дисциплін доцільно передбачати окремі теми, спрямовані на засвоєння цінностей демократії в контексті окремих напрямів. Наприклад, вивчаючи педагогічний менеджмент майбутні магістри дошкільної освіти засвоюють процеси управління освітніми системами з опертям на цінування людської гідності, прав і обов'язків кожного учасника освітнього процесу, оволодівають навичками демократичної культури для ефективної роботи в педагогічному колективі тощо.

2. Формування професійно значущих якостей демократичної особистості. У руслі порушеної проблеми доцільно формувати у майбутніх магістрів компетентності, які допоможуть ефективно реалізувати культуру демократії в професійному, громадянському й особистісному вимірах. У змісті таких компетентностей виокремлюють чотири взаємопов'язані й взаємообумовлені компоненти, а саме: цінності (людська гідність, справедливість, рівність, свобода), ставлення (відкритість до культурної інакшості, переконань, світоглядів, повага, громадянська свідомість, відповідальність, самоефективність), навички (автономного навчання, аналітичного і 
критичного мислення, емпатія, співпраці, комунікації), знання і розуміння (знання і критичне розуміння себе, знання мови, знання і критичне розуміння світу (культури, релігії, історії, економіки, довкілля) тощо) [5, с. 14]. Формування перелічених компонентів здійснюється не лише в процесі професійної підготовки магістрів, необхідно враховувати здобутки попередніх етапів навчання та особистісний досвід.

3. Використання активних форм і методів навчання в освітньому процесі 3ВО. Одними 3 найбільш ефективних для формування культури демократії вважаємо роботу в малих групах, оскільки така діяльність передбачає активну взаємодію, продуктивну комунікацію, пошук спільних рішень, толерантність і повагу до ідей членів групи, самокритичність, аналітичне мислення тощо. Такі інтерактивні методи як “мозковий штурм", “табу”, “інтелект-карта", “система цінностей” та їх модифікації доцільно використовувати під час лекційних та практичних занять 3 різних дисциплін, які передбачені навчальними планами магістерської підготовки спеціальності "Дошкільна освіта". Демократизації використання перелічених методів сприяє встановлення зворотного зв'язку, який передбачає виявлення труднощів у процесі навчання, усвідомлення майбутніми магістрами власних навчальних можливостей та інтересів тощо. Таким чином викладач отримує інформацію про ефективність використовуваних методів і може коригувати їх залежно від потреб і можливостей майбутніх педагогів.

4. Стимулювання партнерських відносин між усіма учасниками освітнього процесу. 3 одного боку такі відносини формуються між викладачем і студентами, а 3 іншого - безпосередньо у студентському середовищі. Важливим $\epsilon$ створення атмосфери співтворчості й активне використання діалогічних методів навчання, які сприяють формуванню в студентів почуття власної гідності, розуміння ними цінності та значущості професійної позиції. Педагог при цьому $є$ рівноправним партнером у спілкуванні 3 майбутніми магістрами і створює умови для того, щоб кожен міг пізнати істину власним шляхом [7, с. 321]. Водночас посилюється особиста відповідальність майбутнього педагога за результати професійної підготовки і стимулюються самоосвітня діяльність.

У руслі порушеної проблеми погоджуємося 3 думкою І.Силадій про те, що демократизація освітнього процесу не може бути самоціллю, перш за все необхідно забезпечити духовно-інтелектуальний простір для самореалізації особистості та розкриття творчого потенціалу кожного студента $[11$, с. 240]. Вважаємо, що реалізація особистісно орієнтованого підходу в професійній підготовці майбутніх магістрів дошкільної освіти забезпечує можливість урахування потреб, можливостей, інтересів, мотивів усіх учасників освітнього процесу і дозволяє формувати культуру демократії у середовищі закладу вищої освіти.

Висновки та перспективи подальших досліджень. Таким чином, демократизація професійної підготовки майбутніх магістрів передбачає: створення можливостей для вибору освітньої траєкторії майбутніми педагогами, наявність вибіркових дисциплін, варіативність форм і методів засвоєння знань, умінь, навичок; оволодіння майбутніми магістрами культурою демократії в процесі відповідного наповнення змісту навчальних дисциплін та використання активних форм і методів навчання; партнерські взаємовідносини між учасниками освітнього процесу на засадах демократичних цінностей тощо. Вважаємо, що навчаючись в атмосфері демократизму магістри дошкільної освіти зможуть у майбутній професійній діяльності створити середовище для розвитку кожної особистості і при цьому спиратимуться на громадянські та демократичні цінності. Перспективи подальших 
досліджень вбачаємо у визначенні шляхів демократизації професійної педагогічної підготовки майбутніх магістрів дошкільної освіти засобами інноваційних освітніх технологій.

\section{Література}

1. Береза В. Поняття політичної освіти і просвітництва в сучасній політологічній літературі. URL : http://irbis-nbuv.gov.ua/cgi-bin/irbis_nbuv/cgiirbis_64.exe?C21COM=2\&I21DBN=UJRN\&

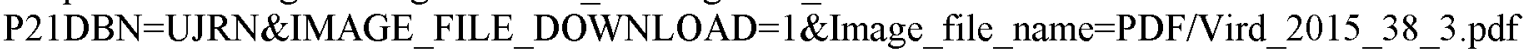

2. Вишневський $\mathrm{O}$. Теоретичні основи сучасної української педагогіки : посібник для студентів. Дрогобич : Коло, 2006. $326 \mathrm{c}$.

3. Закон України "Про освіту". URL : https://zakon.rada.gov.ua/laws/show/2145-19

4. Іванова Т., Фещенко О. Демократизація освіти в державному управлінні - ознака європейської системи. Наукові розвідки з державного та муніципального управління. 2015. № 1. С.27-33.

5. Компетентності для культури демократії - живемо разом як рівноправні громадяни в культурно багатоманітному демократичному суспільстві. Наук. редактор О.Овчарук. Київ : Європейський центр імені Вергеланда, 2018. 78 с.

6. Марусинець М. Формування інтегральної психолого-педагогічної компетентності викладача закладу вищої освіти. Освітній простір України. 2018. Випуск 14. С.81-88.

7. Мачинська Н. І. Педагогічна освіта магістрантів вищих навчальних закладів непедагогічного профілю: монографія. Львів : ЛьвДУВС, 2013. 416 с

8. Подмазин С. И. Личностно-ориентированное образование : Социальнофилософское исследование. Запорожье : Просвіта, 2000. 250 с.

9. Про затвердження концепції розвитку педагогічної освіти. URL : https://mon.gov.ua/ua/npa/prozatverdzhennya-koncepciyi-rozvitku-pedagogichnoyi-osviti

10. Національна стратегія розвитку освіти в Україні на період до 2021 року. URL https://zakon.rada.gov.ua/laws/show/344/2013

11. Силадій I. Демократизація освіти як свобода вибору моделі освітнього процесу. Гілея: науковий вісник. 2018. Вип. 128. С. 277-280.

\section{References}

1. Bereza V. Poniattia politychnoi osvity i prosvitnytstva $\mathrm{v}$ suchasnii politolohichnii literaturi. URL : http://irbis-nbuv.gov.ua/cgi-bin/irbis_nbuv/cgiirbis_64.exe?C21COM=2\&I21DBN=UJRN\&

P21DBN=UJRN\&IMAGE_FILE_DOWNLOAD=1\&Image_file_name=PDF/Vird_2015_38_3.pdf

2. Vyshnevskyi $\mathrm{O}$. Teoretychni osnovy suchasnoi ukrainskoi pedahohiky : posibnyk dlia studentiv. Drohobych : Kolo, 2006. $326 \mathrm{~s}$.

3. Zakon Ukrainy "Pro osvitu". URL : https://zakon.rada.gov.ua/laws/show/2145-19

4. Ivanova T., Feshchenko O. Demokratyzatsiia osvity v derzhavnomu upravlinni - oznaka yevropeiskoi systemy. Naukovi rozvidky z derzhavnoho ta munitsypalnoho upravlinnia. 2015. № 1 . S.27-33.

5. Kompetentnosti dlia kultury demokratii - zhyvemo razom yak rivnopravni hromadiany $\mathrm{v}$ kulturno bahatomanitnomu demokratychnomu suspilstvi. Nauk. redaktor O.Ovcharuk. Kyiv : Yevropeiskyi tsentr imeni Verhelanda, 2018. $78 \mathrm{~s}$

6. Marusynets M. Formuvannia intehralnoi psykholoho-pedahohichnoi kompetentnosti vykladacha zakladu vyshchoi osvity. Osvitnii prostir Ukrainy. 2018. Vypusk 14. S.81-88.

7. Machynska N. I. Pedahohichna osvita mahistrantiv vyshchykh navchalnykh zakladiv nepedahohichnoho profiliu: monohrafiia. Lviv : LvDUVS, 2013.416 s

8. Podmazyn S. Y. Lychnostno-oryentyrovannoe obrazovanye : Sotsyalnofylosofskoe yssledovanye. Zaporozhe : Prosvita, 2000.250 s.

9. Pro zatverdzhennia kontseptsii rozvytku pedahohichnoi osvity. URL : https://mon.gov.ua/ua/npa/prozatverdzhennya-koncepciyi-rozvitku-pedagogichnoyi-osviti

10. Natsionalna stratehiia rozvytku osvity $v$ Ukraini na period do 2021 roku. URL https://zakon.rada.gov.ua/laws/show/344/2013

11. Syladii I. Demokratyzatsiia osvity yak svoboda vyboru modeli osvitnoho protsesu. Hileia: naukovyi visnyk. 2018. Vyp. 128. S. 277-280. 